\title{
PERKEMBANGAN AKTIVITAS ENZIM PENCERNAAN PADA LARVA/BENIH IKAN BAUNG (Mystus nemurus C.V.)
}

\begin{abstract}
Yanti Suryanti
\section{ABSTRAK}

Aktivitas enzim pencernaan adalah suatu indikator yang baik untuk menentukan kapasitas enzim pencernaan pada larva. Saat aktivitas tinggi, dapat diindikasikan secara fisiologis bahwa larva telah siap untuk memproses pakan dari luar. Tujuan penelitian ini adalahuntuk mengetahui perkembangan aktivitas enzim pencernaan larva baung, yang diharapkan dapat dijadikan sebagai pendekatan untuk menentukan saat awal yang tepat untuk pemberian pakan buatan. Larva/benih yang digunakan berumur 2-15, 20, 25, 30, 35, 40 hari. Enzim pencernaan yang dianalisis meliputi protease dan lipase. Hasil penelitian menunjukkan bahwa aktivitas protease dan lipase meningkat sejalan dengan meningkatnya umur. Perubahan maksimum aktivitas enzim terjadi pada umur 13 hari.
\end{abstract}

ABSTRACT: Digestive enzyme development of Malaysian catfish larvae (Mystus nemurus C.V.). By: Yanti Suryanti

Digestive enzyme activity is a good indicator of larval digestive capacity. High enzyme activity indicaties that the larvae has become physiologically ready to process exogenous food. The aim of this experiment was to know the development of digestive enzyme activity of Malaysian catfish larva, which can be used to determine its first used feeding. Malaysian catfish larva of 2-15, 20, 25 , $30,35,40$ days old were as samples for protease and lipase activities assay. The result of this experiment showed that protease and lipase activities increased in line with the increase of larval age. Maximum change of enzyme activity was found on larvae 13 day old.

KEYWORDS: digestive enzyme development, larval/seed, malaysian catfish

\section{PENDAHULUAN}

Ikan baung (Mystus nemurus C.V.) merupakan salah satu jenis ikan lokal yang terdapat di beberapa perairan sungai seperti di Sumatera, Jawa, dan Kalimantan. Pada stadia awal daur hidupnya ikan baung belum mampu memanfaatkan pakan buatan, karena pada stadia tersebut sistem pencernaannya masih sederhana dan belum berdiferensiasi baik secara morfologis maupun fisiologis. Sebagaimana halnya pada hewan lain sistem pencernaan tersebut akan berkembang menuju kesempurnaan sejak larva ikan menetas hingga umur tertentu. Kesempurnaan sistem pencernaan tersebut dapat mempengaruhi produksi enzim pencernaan seperti pada pankreas, lambung, dan dinding usus.

Menurut Dabrowski (1979), struktur morfologis saluran pencernaan yang sederhana berkorelasi dengan rendahnya produksi enzim. Kemampuan larva/ benih ikan dalam mencerna pakan terutama pakan buatan sangat tergantung kepada kelengkapan alat pencernaan termasuk ketersediaan enzim pencernaan, sehingga jika pemberian pakan buatan tidak pada waktu yang tepat berdasarkan keter- sediaan enzim pencernaannya, maka larva tidak mampu mencerna dan memanfaatkan pakan buatan secara optimal.

Aktivitas enzim pencernaan bervariasi menurut umur ikan, fisiologis, dan musim (Hepher, 1988). Penelitian tentang perkembangan aktivitas enzim pencernaan sudah banyak dipublikasikan di antaranya: larva betutu (Effendi, 1995); larva gurami (Affandi et al., 1994); larva Dicentrachus labrax (Vu, 1983); Coregonus sp. (Lauff \& Hofer, 1984); Chanos chanos (Ferraris et al., 1987); Ctenopharyngodon idella (Das \& Tripathi, 1991). Aktivitas enzim pencernaan adalah suatu indikator yang baik untuk menentukan kapasitas pencernaan, saat aktivitas tinggi dapat diindikasikan secara fisiologis larva siap untuk memproses pakan dari luar.

Dengan demikian, penelitian perkembangan aktivitas enzim pencernaan ini diharapkan dapat dijadikan sebagai acuan atau pendekatan untuk menentukan saat yang tepat bagi pemberian pakan buatan terhadap larva ikan baung.

\footnotetext{
*) Peneliti pada Balai Penelitian Perikanan Air Tawar, Sukamandi
} 


\section{BAHAN DAN METODE}

Analisis aktivitas enzim dilakukan di laboratorium biokimia, FMIPA-IPB. Aktivitas enzim yang dianalisis meliputi protease dan lipase. Pengukuran aktivitas enzim diambil dari ekstrak enzim melalui penggerusan larva ikan setiap kelompok umur 2-15, 20, 25, 30, 35, dan 40 hari sejak menetas. Untuk mendapatkan larva dari setiap kelompok umur, larva dari umur 1 hari dipelihara dalam akuarium dengan volume $100 \mathrm{~L}$ sebanyak 10 buah, kepadatan setiap akuarium 5 ekor/ $L$ dengan masa pemeliharaan 1-40 hari. Larva yang digunakan sebanyak 5.000 ekor untuk memungkinkan pengambilan contoh ikan yang memadai. Pada masa pemeliharaan, media dipertahankan dengan dilengkapi alat pemanas dan aerator sehingga pada kondisi baik yaitu suhu $27^{\circ} \mathrm{C}-28^{\circ} \mathrm{C}$, oksigen $6,5-7,0 \mathrm{mg} / \mathrm{L}$, dan $\mathrm{pH}$ 7-8 serta larva diberi pakan berupa artemia sampai ikan kenyang. Setelah larva mencapai umur yang diinginkan, sampel diambil sebanyak $1 \mathrm{~g}$ untuk digerus dan diambil ekstraknya untuk dianalisis. Sebelum pengambilan sampel, larva yang akan digunakan untuk sampel dipisahkan kemudian dipuasakan satu hari. Prosedur yang digunakan untuk protease ialah prosedur yang digunakan oleh Fengxie (1988) dalam Widjajanti (1993) dengan menggunakan substrat kasein dan sebagai standar tirosin, pengukuran dilakukan menggunakan spektrofotometer dan analisis lipase menggunakan metode turbidimetrik. Analisis lipase menggunakan alat kit dari randox dengan metode turbidimetrik dan sebagai substrat adalah triolein.

Aktivitas enzim dinyatakan sebagai satuan unit aktivitas enzim $/ \mathrm{mL}$ contoh/menit. Aktivitas protease ditentukan dengan mengukur kemampuan enzim untuk menghidrolisis protein sehingga dihasilkan tirosin yang dibebaskan, diukur secara kolorimetrik.

Aktivitas lipase diukur dengan menggunakan triolein sebagai substrat. Asam lemak yang dibebaskan membentuk garam asam lemak yang mengendap. Selanjutnya garam tersebut diukur secara turbidimetrik pada panjang gelombang $340 \mathrm{~nm}$.

\section{HASIL DAN BAHASAN}

Hasil analisis aktivitas enzim pencernaan pada larva ikan baung menunjukkan aktivitas protease dan lipase meningkat sesuai perkembangan umur ikan. Hal ini disajikan pada Tabel1.

Selanjutnya dari hasil perkembangan aktivitas enzim tersebut dilakukan penghitungan perubahan relatif aktivitas enzim pada umur (hari) tertentu terhadap umur (hari) sebelumnya. Hal ini disajikan pada Gambar 1.

Tabel 1. Aktivitas protease dan lipase ( $\mathrm{m} / \mathrm{mL} /$ menit) pada larva/benih ikan baung

Table 1. Protease and lipase activities ( $\mathrm{m} / \mathrm{mL} / \mathrm{min}$.) of Malaysian catfish larvae

\begin{tabular}{ccc}
\hline $\begin{array}{c}\text { Umur (hari) } \\
\text { Age (day) }\end{array}$ & $\begin{array}{c}\text { Aktivitas Protease } \\
\text { Protease activity } \\
\text { (m/mL/menit) (m/mL/min.) }\end{array}$ & $\begin{array}{c}\text { Aktivitas Lipase } \\
\text { Lipase activity } \\
\text { (m/mL/menit) (m/mL/min.) }\end{array}$ \\
\hline 2 & 0.216 & 0.267 \\
3 & 0.170 & 0.148 \\
4 & 0.148 & 0.296 \\
5 & 0.224 & 0.593 \\
6 & 0.256 & 0.653 \\
7 & 0.294 & 0.683 \\
8 & 0.318 & 0.742 \\
9 & 0.320 & 0.794 \\
10 & 0.342 & 0.831 \\
11 & 0.376 & 0.890 \\
12 & 0.384 & 0.979 \\
13 & 0.528 & 1.187 \\
14 & 0.572 & 1.335 \\
15 & 0.616 & 1.484 \\
20 & 0.676 & 1.660 \\
25 & 0.737 & 1.817 \\
30 & 0.742 & 1.848 \\
35 & 0.778 & 1.929 \\
40 & 0.838 & 2.107 \\
\hline
\end{tabular}




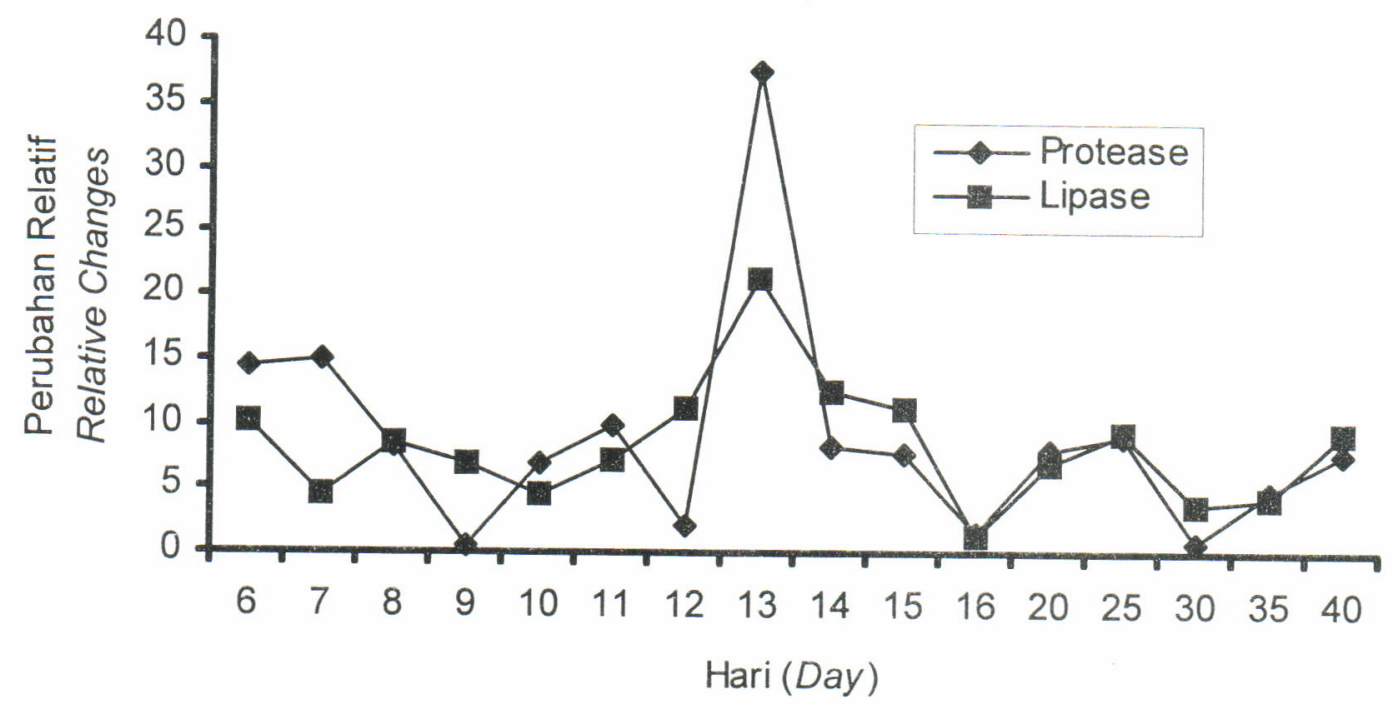

Gambar 1. Perubahan relatif aktivitas protease dan lipase

Figure 1. Relative changes of protease and lipase activity

Analisis aktivitas enzim dilakukan mulai larva umur 2 hari, pada saat ini larva baung belum memperoleh makanan dari luar. Hasil analisis menunjukkan bahwa larva umur 2 hari telah mempunyai protease maupun lipase. Hal ini terjadi karena adanya proses metabolisme kuning telur yang ada pada larva. Pada kuning telur, ikan mengandung asam amino dan lipid, jadi larva tersebut memperoleh energi dari hasil katabolisme asam amino fosfolipid yang terdapat pada kuning telur.

Cadangan asam amino dan lemak pada kuning telur akan dihidrolisis oleh enzim protease dan lipase untuk dihasilkan energi bebas. Ketergantungan terhadap kuning telur terjadi selama fase penyerapan kuning telur, sampai larva membangun sistem organ secara cukup untuk memperoleh makanan dari luar. Selama fase penyerapan kuning telur, nutrien kuning telur mengalami penurunan, dan jika nutrien kuning telur tidak cukup untuk mendukung metabolisme pada larva, larva harus memperoleh makanan dari luar.

Pada saat menjelang hari ke-3 larva mulai diberi pakan alami (artemia), walaupun kuning telur masih ada, namun nutrien kuning telur tersebut telah mengalami penurunan. Pada hari ke-3 kuning telur habis, sehingga aktivitas enzim protease dan lipase mengalami penurunan. Pada hari ke-4 protease masih mengalami penurunan, namun pada aktivitas lipase dengan adanya pakan alami (artemia) aktivitasnya meningkat sejalan dengan umur ikan yaitu dari umur 4 hari hingga umur 40 hari meningkat dari $0,296 \mathrm{~m} /$ $\mathrm{mL} /$ menit menjadi $2,107 \mathrm{~m} / \mathrm{mL} /$ menit. Aktivitas protease mengalami peningkatan setelah hari ke-4, yaitu dari umur 5 hari hingga umur 40 hari meningkat dari
$0,224 \mathrm{~m} / \mathrm{mL} /$ menit menjadi $0,838 \mathrm{~m} / \mathrm{mL} /$ menit Peningkatan aktivitas enzim protease dan lipase oleh adanya substrat makanan yang dimakan larva, sehingga memberikan kontribusi terhadap aktivitas endogenous enzim.

Pakan alami yang digunakan dalam penelitian ini adalah artemia. Dari hasil analisis aktivitas enzim pada artemia tersebut, aktivitas protease $0,248 \mathrm{~m} / \mathrm{mL} /$ menit dan lipase $0,413 \mathrm{~m} / \mathrm{mL} /$ menit. Berdasarkan hasil penelitian Gawlicka et al. (2000), bahwa kontribusi aktivitas protease dan lipase dari artemia terhadap total aktivitas enzim pencernaan larva relatif kecil (2-10\%) dibanding aktivitas amilase. Hal ini terjadi menurut Semain et al. (1980) dalam Gawlicka (2000), nauplius artemia merupakan herbivora yang diperkirakan mempunyai aktivitas amilase tinggi untuk mencerna karbohidrat. Dengan demikian walaupun relatif kecil, adanya artemia yang dimakan oleh larva ikan akan memberikan kontribusi sebagai enzim eksogenous dan memicu terhadap perkembangan aktivitas enzim endogenous.

Pada umur 7-8 hari baik aktivitas enzim protease maupun lipase terjadi perubahan relatif besar paling awal, hal ini diduga selain adanya kontribusi dari pakan juga enzim endogenous sudah berkembang. Perubahan relatif terbesar terjadi pada umur 13 hari, hal ini terjadi baik pada protease maupun lipase. Saat tingginya perubahan tersebut dapat dijadikan dasar untuk dapat memberikan pakan buatan terhadap benih ikan baung, karena pada saat tersebut diduga aktivitas endoenzim sudah dapat mencerna pakan buatan yang lebih kompleks. Berdasarkan hasil penelitian Tang (2000) pada benih ikan baung umur 12 hari, lambung 
sudah dapat dibedakan dengan usus serta di antara lambung dan usus terdapat saluran pencernaan ( $p y-$ lorus). Oleh karena itu tingginya aktivitas protease dan lipase pada hari ke-13 disebabkan sistem pencernaan pada benih tersebut mulai sempurna sejak umur 12 hari.

Penyebab kedua peningkatan aktivitas enzim ini ada kaitannya dengan perkembangan alat pencernaan (Arlia, 1994). Dengan bertambahnya umur larva ikan, organ tubuh termasuk alat pencernaan ini akan mempengaruhi produksi enzim pencernaan, karena enzim pencernaan tersebut diproduksi oleh kelenjar yang terdapat pada alat pencernaan tersebut, yaitu: pankreas, lambung, dan dinding usus (Kapoor et al., 1975)

Pada struktur anatomis dan histologis alat pencernaan masih belum sempurna, enzim endogen yang disekresikan sangat sedikit. Hal ini dicerminkan oleh aktivitas enzim protease dan lipase yang masih rendah. Dengan bertambahnya umur larva ikan maka struktur anatomis dan histologis ikan bertambah sempurna hingga mencapai bentuk definitif. Setelah mencapai bentuk definitif, enzim pencernaan meningkat sehingga ikan akan mampu mencerna pakan yang tidak mengandung enzim (pakan buatan).

Peningkatan aktivitas enzim baik protease maupun lipase dari umur 4 hari hingga umur 40 hari disebabkan oleh perkembangan alat pencernaan ikan ke bentuk definitif dan hal ini sejalan dengan pertumbuhan larva ikan baung.

\section{KESIMPULAN}

Kesimpulan yang dapat diberikan dari hasil penelitian ini adalah:

1. Aktivitas enzim protease dan lipase pada larva/ benih ikan baung meningkat sejalan dengan meningkatnya umur ikan sampai 40 hari. dan perubahan relatif aktivitas enzim maksimum terjadi pada umur 13 hari.

2. Pada umur 3-4 hari kuning telur pada larva baung telah habis, jadi merupakan saat kritis di mana ikan harus diberi makanan dari luar.

3. Saat perubahan relatif aktivitas enzim maksimum yaitu pada umur 13 hari dapat dijadikan saat yang tepat untuk memberikan pakan buatan.

\section{DAFTAR PUSTAKA}

Affandi, R., I. Mokoginta, dan A. Suprayudi. 1994. Perkembangan enzim benih ikan gurame. Osphronemus gouramy. Jurnal IImu-IImu Perairan dan Perikanan Indonesia. 2(2):63--71.

Arlia, L. 1994. Pengaruh Kadar Protein Pakan Buatan terhadap Pertumbuhan Benih Ikan Gurame (Osphoronemus gouramy Lacepede). Tesis Program Pascasarjana IPB. 65 pp.

Dabrowski, K. 1979. The feeding of fish larvae: present (stage of the art) and perspective. Reprod. Nutr. Develop. 24(6): 807--833.

Das, K.M. and Tripathi. 1991. Studies on the digestive enzymes of grass carp, Ctenopharyngodon idella (Val.). Aquaculture. 92:21--32

Effendi, I. 1995. Perkembangan Enzim Pencernaan Larva Ikan Betutu, Oxyeleotris marmorata (Belkr) yang Dipelihara pada Cahaya Normal dan Teduh. Tesis Magister Sains, Program Pascasarjana, Institut Pertanian Bogor. Bogor. 69 pp.

Ferraris, R.P., J.D. Tan, and M.C. Delta Cruz. 1987. Development of the digestive tract of milkfish, Chanoschanos (Forskal): histology and histochemistry. Aquaculture. 61:241--257

Gawlicka, A., P. Brigitte, M.H. Horn, R. Neil, O. Ingegjerd, and J.T. Ole. 2000. Activity of digestive enzymes in yolk-sac larvae of Atlantic halibut (Hippoglossus hippoglossus): indication of readiness for first feeding. Aquaculture. 184:303--314

Hepher, B. 1988. Nutrition of Pond Fishes. Cambridge University Press, Cambridge, New York. 388 pp.

Kapoor, B.G., H. Smith, and E.A. Verighina. 1975. The alimentary canal and digestion in Teleost. In: Russel, F.S. and M. Young (Eds.). Mar. Biol. 13. Acad. Press. London, New york. San Francisco. p. 109--211.

Lauff, M. and R. Hofer. 1984. Proteolytic enzymes in fish development and the importance of dietary enzyme. Aquaculture. 37: 335--346.

Tang, U.M. 2000. Kajian Biologi, Pakan, dan Lingkungan pada Awal Daur Hidup Ikan Baung (Mystus nemurus Cuvier \& Valenciennes 1945). Disertasi. Program Pascasarjana. Institut Pertanian Bogor. 118 pp.

Widjajanti, D. 1993. Studi Aktivitas Protease pada Benih Ikan Gurame (Osphronemus gouramy Lac.) dengan Perbedaan Saat Awal Pemberian Pakan Buatan. Skripsi Program Studi Manajemen Sumberdaya Perairan, Fakultas Perikanan IPB. 62 pp.

Vu, T.T. 1983. A histoenzymological study of protease activities in the digestive tract of larvae and adult of sea bass, Dicentrachus labrax (L). Aquaculture. 32:57--67. 